\title{
Trade Liberalization, Import Penetration and Unionization: The U.S. Experience
}

\author{
Ayfer Gurun1, G. Geoffrey Booth ${ }^{2}$ \\ ${ }^{1}$ Naveen Jindal School of Management, University of Texas at Dallas, Richardson, TX, USA \\ ${ }^{2}$ Eli Broad College of Business Administration, Michigan State University, East Lansing, MI, USA \\ Email: axg119030@utdallas.edu, boothg@msu.edu
}

Received 4 December 2015; accepted 1 February 2016; published 5 February 2016

Copyright (C) 2016 by authors and Scientific Research Publishing Inc.

This work is licensed under the Creative Commons Attribution International License (CC BY). http://creativecommons.org/licenses/by/4.0/

(c) (i) Open Access

\section{Abstract}

In the aftermath of World War II there has been a worldwide trend for countries to pursue policies to enhance free trade in order to improve their economic wellbeing. Nevertheless the benefits are associated with free trade and many generate unwanted consequences to segments of a nation's populace. With this thought in mind, we investigate the impact of import penetration originating from low-wage countries on the unionization rates in U.S. We find that import penetration originating from low-wage countries decreases unionization rates, with a $1 \%$ increase in import penetration reducing unionization rates by slightly less than $2 \%$ within three years after controlling for several factors that may affect unionization rates. If only imports from China and India (both low-wage countries) are considered, the reduction almost doubles. Our findings are consistent with the argument that firms are reluctant to collaborate and contract with unions that ask for sticky labor costs and multiyear contracts because these provisions often result in declining profit margins.

\section{Keywords}

Imports, Unions, Employment, Trade Agreements, Tariffs

\section{Introduction}

Since the late 1940s, the general focus of trade policy of the U.S. and other leading trading nations of the world has been to reduce or eliminate artificial barriers to trade such as tariffs, import quotas, domestic content requirements and export subsidies. This long-term initiative began with the establishment of the General Agreement on Tariffs and Trade (GATT), which took effect in 1948 and lasted until it reconfigured and expanded itself into the World Trade Organization (WTO) in 1995, an accomplishment that took eight years of discussion 
and political accommodation. In the last three decades, the U.S. has actively engaged in trade liberalization activities and has created several significant trade agreements involving one or more countries. Key examples include the Canadian-U.S. Free Trade Agreement (1988), the North American Free Trade Agreement (1992), the Central American Free Trade Agreement (2005), the South Korea-U.S. trade agreement (2007) and most recently the Trans-Pacific Partnership Agreement (2015). ${ }^{1}$

The argument for free trade is well known and rests largely on the pioneering works of Adam Smith and David Ricardo in the late $18^{\text {th }}$ and early $19^{\text {th }}$ centuries. ${ }^{2}$ Briefly stated, the argument asserts that the joint economic output and, hence, economic welfare is greater for each trading partner than the sum of the individual outputs if trading is not possible. This occurs because the economic skills and resources of the trading partners are unlikely to be the same and trading permits these differences to be exploited productively. Not covered by the economics of the argument are other important societal considerations such as foreign policy concerns, human dignity and rights, and political stability issues, to name but a few. Thus, it is possible that achieving the economic gains associated with freer trading may only be achieved at the cost of not reaching one or more important noneconomic goals and may have unintended and unwanted consequences.

It is not surprising, therefore, that there is not unanimous support for free trade. In this regard, Griswold [3] cogently points out that the leaders of organized labor (i.e., unions) in the U.S. have “...virtually opposed all legislative initiatives since the 1980s to reduce barriers to free trade.....”3 He points out that these labor leaders argue that past trade liberalization policies have reduced their unions' political power, and "[t]hey see import competition and the ability of U.S. companies to locate production abroad as direct threats to the living standards and bargaining leverage of the union members that they represent."

Historically, trade has largely involved manufactured goods. In the last few decades, the percent of U.S. workers involved in manufacturing declined by $50 \%$. During the same time period manufacturing's share of Gross Domestic Product (GDP) declined by $50 \%$ as well. ${ }^{5}$ This decline seems to be broadly consistent with the union argument. The link between manufacturing decline and union strength, however, may not be so straightforward. For example, Bernard, Jensen and Schott [7] suggest that increased trade with low-income countries may be one of the reasons for these declines rather than increased trade in general. They find that firms exposed to imports from low-wage countries have lower growth rates and lower survival probabilities. They also show that these exposed firms tend to rework their production methods to include more capital- and skill-intensive processes. Although their results suggest that employment in these affected industries declines over time, the implications concerning unionization is at best murky since it is unclear as to whether their production reorientation will involve more or less union labor, especially if the importing country is a high-wage country.

The purpose of this paper is to investigate empirically the influence of import penetration originating from low-wage countries on unionization rates in the U.S., which is a high-wage country. Our data begin in 1989 and end in 2008. Although our period of study is dictated by data availability, it is rich in content since it includes to some extent four different U.S. involved trade agreements including NAFTA, the North American Free Trade Agreement. The link between import penetration originating from low-wage countries and unionization rates is important because, as Chen, Kacperczyk and Ortiz-Molina [8] point out, unions often impact a firm's restructuring decisions and make its adjustment of labor and physical capital stock more costly. If international trade from low-wage countries creates competition for domestic firms, then employers' opposition to unionization may increase and/or unions may lose bargaining power to negotiate contract terms (the negotiation power hypo-

\footnotetext{
${ }^{1}$ The dates associated with the trade liberalization initiatives refer to when the initial agreement was completed. It often took many years to modify the agreements until eventually accepted by the governments involved. As of the date of this paper the Trans-Pacific Partnership has passed the initial agreement stage but has not yet received the final approval of the U.S. government.

${ }^{2}$ Their contributions, as illustrated in Smith [1] and Ricardo [2], are considered by many economists and historians to be part of the foundation of modern economics.

${ }^{3} \mathrm{~A}$ recent exception appears to be the South Korea - U.S. trade agreement. Schneider [4] points out that "[t] he United Autoworkers union and key auto-state legislators in both parties also have endorsed the final agreement.” He also reports that a spokesperson for the Obama White House in reference this agreement stated that "[i]t has been a long time since a union supported a trade agreement..."

${ }^{4}$ Unions have not always been hostile to the concept of free trade as evinced by their support of the Reciprocal Trade Agreements Act (1934) and the Trade Expansion Act (1962). Simmons [5] suggests that the early support of free trade initiatives by labor was because of their belief that reducing tariffs was tantamount to decreasing the cost of living through the lowering of prices.

${ }^{5}$ Bailey and Bosworth [6] report that average manufacturing output as a percentage of total GDP in real terms was about $12 \%$ between 1960 and 2012 (see their Figure 1). However, during the same time, manufacturing employment as a share of total U.S. work force declined from $33 \%$ to $10 \%$ between 1950 and 2013. More importantly, the number of persons engaged in production (measured as full-time equivalent employees plus the self-employed) shows a sharp decline from 1980 to 2010, a period that spans the four recent trade agreements as well as our research sample.
} 
thesis). This might happen because firms may be reluctant to agree to sticky labor costs and multiyear contracts, which may result in declining profit margins. The negotiation power hypothesis predicts a negative relation between import penetrations by low-wage countries and changes in unionization.

Import penetration, however, is not necessarily exogenous to the determination of future changes in the unionization rate for at least three reasons. First, low-wage countries may target industries in which unionization rates have deteriorated. Stated differently, the unionization rate may be declining for an unobserved reason, and low-wage countries happen to concentrate their export efforts in these industries (an instance of reverse causality). Second, low-wage countries may target industries with strong union activities in order to take advantage of the higher adjustment costs often associated with incumbent domestic firms. Finally, highly unionized industries may also enjoy protection from politicians who create barriers to limit the activity of foreign competitors. To handle the econometric issues associated with the possible lack of exogeneity, we employ a two-stage regression procedure involving instrumental variables.

Our empirical results are consistent with the negotiation power hypothesis, i.e., we find that increasing the low-wage country import penetration by $1 \%$ reduces unionization rates by $1.88 \%$ within three years after controlling for several factors that may affect unionization rates. If only imports from China and India (both low-wage countries) are considered, the reduction almost doubles to $3.71 \%$. Furthermore, we find that the impact of import penetration on the unionization rate of those countries that are not classified as low-wage is one-third the magnitude of the impact associated with the low-wage countries. Our results are stronger when we calculate import penetration coming only from India and China. These findings suggest that imports from low-wage countries indeed have distinct effects.

The economic magnitude of our result provides important insights to ongoing discussion on the effect of unions on firms' flexibility to adjust their operating costs. Chen, Kacperczyk and Ortiz-Molina [8] show that operating leverage, measured by the elasticity of a firm's labor costs with respect to its sales, is negatively correlated with the unionization level of a firm's industry. In addition, Bernard, Jensen and Schott [7] note that because of the high relative wages in U.S., "[i]t is virtually impossible for the U.S. to survive head-to-head competition with the world's most labor-abundant countries in labor-intensive industries," as predicted by standard trade models. Consistent with our findings and the results of Bernard, Jensen and Schott [7], Robinson [9] reports that unions are largely responsible for the deterioration of the operating performance of firms in the automobile industry, which suffers from significant foreign competition. ${ }^{6}$

\section{Relevant Literature}

Our paper combines two strands of literature in economics. From the labor economics literature, our paper relates to research that investigated the determinants of unionization rates. In international economics, our study contributes to the developing literature on the effects of import penetration on firm dynamical behavior.

\subsection{Labor Organizations}

Several factors influence unionization rates. For example, general market conditions affecting unemployment rates should affect both the supply and demand for joining a union in order to be part of a collective bargaining unit. Moreover, regulations governing labor standards and Social Security, union recruitment strategies, unions' prior success in bargaining, and predominant social and political values are important factors that affect unionization rates. Mishel [10] shows that union wage gains are greatest where pricing power enhances employers' ability to pay and where unions achieve high coverage, practice centralize bargaining, and avoid union fragmentation. Chen, Kacperczyk and Ortiz-Molina [8] contend that unions, especially the powerful ones, substantially reduce operating flexibility because they make labor wages more sticky and layoffs more costly. The channel that this may work through may take various forms. For instance, senior workers at unionized firms may benefit more from layoff protection than those at non-unionized firms [11]. Unions may negotiate multi-year contracts that would prevent firms from changing wages in the short run [12] [13]. Unions also may demand job security through high severance payments or clauses to prevent layoffs [14] [15], however, show employers' resistance to trade unionism and union inefficiencies have a negative effect on young workers' decision to join an union.

\footnotetext{
${ }^{6}$ In this particular case, Robinson [9] maintains that unions effectively blocked closure of some of General Motor's existing plants because the United Auto Workers negotiated a contract with the auto producers that enforces a fixed wage "irrespective of the performed work."
} 


\subsection{International Trade}

Bernard et al. [16] suggest that our understanding of international trade in terms of the origins and implications would be enriched if researchers shift their focus of international trade from countries and industries toward firms and products. Along these lines, Bernard, et al. [17] and Melitz and Ottaviano [18] propose models in which the profit margin is endogenous and decreases as import competition intensifies following reductions in trade costs. These authors argue that reduced product margins likely have different implications across firms. Moreover, Melitz's [19] model shows that reductions in trade barriers increase the profitability of existing exporters and reduce the profits of non-exporters. The reduction of profits in the domestic market forces marginally profitable firms to exit the industry. As a result, output and employment are reallocated toward higher-productivity firms, leading to an increase in the average their industry's productivity. While such heterogeneous firm models feature simultaneous job creation and destruction within industries as low-productivity firms exit and high-productivity firms expand, the overall implication on aggregate labor market is ambiguous. From this perspective, heterogeneous firm models predict a relation between international trade and factor prices such as wages. Consequently, the unionization rate, as a function of labor factor prices, is one of the channels through which we can observe the effect of low-wage country penetration.

Influential theory papers such as Krugman [20] and Melitz [19] predict that all workers win from if trade is liberalized. These models, however, assume homogeneous workers and full employment. Davis and Harrigan [21] combine the notions of product and labor market churning and show that liberalization leads to reduction of jobs with above average wages but it has smaller impact on aggregate unemployment. Felbermayr, Pratand Schmerer [22] show that trade liberalization lowers unemployment and raises real wages as long as it improves aggregate productivity net of transport costs. They also show that trade openness on employment is significant when wages are bargained at the individual level but much smaller when wages are bargained at the collective level. For non-exporting firms, Uysal, Yotov and Zylkin [23] show that the number of trade-induced layoffs increases with firm productivity but decreases for exporting firms. They also show that exporting firms may lay off some workers who work in production for their shrinking domestic segments, while also engaging in some within-firm reallocation of workers. Egger and Kreickemeier [24] develop a model that incorporates workers' fair wage preferences into a general equilibrium framework with heterogeneous firms, and show that globalization leads to a simultaneous increase of average profits and involuntary unemployment and also within-group wage inequality.

While neoclassical theory emphasizes the impact of trade on wage inequality between occupations and sectors, more recent theories of firm heterogeneity point to the impact of trade on wage dispersion within occupations and sectors. For example, using linked employer-employee data from Brazil, Helpman et al. [25] show that much of overall wage inequality arises within sector occupations and for workers with similar observable characteristics. Cosar, Guner and Tybout [26] explore the combined effects of reductions in trade frictions, tariffs, and firing costs on firm dynamics, job turnover, and wage distributions. They find that integration with global product markets has increased both average income and job turnover in Colombia. Using data on trade-induced displacements, Kondo [27] shows that regions that face more foreign competition in the U.S. have higher job destruction rates, lower job creation rates, and, consequently, lower employment rates. Yotov [28] shows that trade-induced unemployment and trade-adjustment costs may result in an incumbent politician granting protection to an unorganized industry, even when there is political pressure by organized sectors of the labor market. This is consistent with the theoretical predictions of Grossman and Helpman [29] who argue that the government should protect organized industries but should subsidize imports in unorganized sectors.

\section{Data and Variable Construction}

\subsection{Data Sources}

To test the negotiation power hypothesis, which posits a negative relationship between import penetration and unionization rates, we obtain historical data on U.S. imports, exports, tariffs, foreign direct investment, and unionization by industry from several sources.

U.S. import and export data are from Peter Schott's International Economics Resource Web site (http://www.som.yale.edu/faculty/pks4/sub_international.htm). The import database contains information on which commodity, indicated by the 10-digit Harmonized Tariff Schedule (HTS) Code, was imported from 
which country for every year from 1989 to 2008. The export database contains similar information that shows which commodities were exported to which country for the same 11 year time span. We obtain the eight-digit Harmonized Tariff Schedule (HTS) Code-level tariff data provided by John Romalis, which are available at his Web site http://www.johnromalis.com/. Tariff data cover the years between 1989 and 2001.

We retrieve the foreign direct investments by industry from the OECD's Web site (http://stats.oecd.org/Index.aspx?DataSetCode=FDI_FLOW_INDUSTRY).

Census Industry Classification (CIC)-level unionization data between 1984 and 2006 are gathered from the Union Membership and Coverage Database (www.unionstats.com). This database, which is maintained by Barry Hirsch and David Macpherson, is compiled from the Current Population Survey. Hirsch and Macpherson [30] discuss the details on the construction of this unique and comprehensive dataset.

To merge the unionization data and the export-import databases, we use the concordance file that links 1989-2006 U.S. Harmonized System (HS) codes to U.S. SIC codes provided by Pierce and Schott [31]. They describe the concordances between the 10-digit HS categories used to classify products in U.S. international trade that cover the years 1989 to 2006. Because the data for import penetration and unionization are constructed using different industry definitions, we use a common denominator, two-digit SIC code level industry definition to merge the data.

\subsection{Variable Descriptions}

Our dependent variable, C3UNION, is the change in unionization rate in an industry within three years following the year import penetration is measured. To measure labor force unionization rate (UNION), we follow Connolly, Hirsch and Hirschey [32] and measure unionization in industry $i$ in time $t$ as the percentage of employed workers in a firm's primary industry covered by unions in the collective bargaining with the employers, i.e.:

$$
\text { UNION }_{i, t}=100\left(\text { Union Members }_{i, t} / \text { Total Employees }{ }_{i, t}\right) \text {. }
$$

There may be several unions in a given industry; however, data do not allow us to identify unions by name. Therefore, the unionization measure basically captures the percentage of labor affiliated to unions. Because our industry definition is at the two-digit SIC code level, we are able to capture the spillover effects within an industry. For example, any import penetration shock occurring in the household furniture industry (SIC code 2510) may potentially impact the office furniture industry (SIC code 2520) because they have the same two-digit SIC code (25). Similarly, any import penetration in the knitting mills industry (SIC code 2253) may also affect the carpet and rugs industry (SIC code 2273).

We define the change in unionization rate as:

$$
\text { C3UNION }_{i, t \text { to } t+3}=\text { UNION }_{i, t+3}-\text { UNION }_{i, t} \text {. }
$$

We choose a change period of three years to accommodate the possibility that a unionization decision (voluntarily or forced) may take time to respond to import penetration shock. We use one and two year horizons to investigate the robustness of this time difference.

We compute two import penetration measures. Our low-wage-country import penetration measure is:

$$
\operatorname{LWPEN}_{i t}=\left(M_{i t}^{L}\right) /\left(M_{i t}-X_{i t}\right),
$$

where $M_{i t}^{L}$ and $M_{i t}$ represent the value of imports from low-wage countries and all countries in industry $i$ and year $t$, respectively, and $X_{i t}$ represents U.S. exports. This measure has the advantage of not only considering where imports originate and but also their amounts. We follow Bernard, Jensen \& Schott [7] and classify a country as low wage in year $t$ if its per capita GDP is less than 5\% of U.S. per capita GDP. Their list of 52 countries, which is provided in the Appendix, contains well-known countries such as China and India as well as lesser known ones such as Lesoto and Togo. ${ }^{7}$ Similarly, our import penetration measure for countries not classified as low-wage, i.e., other-wage is:

$$
\operatorname{OWPEN}_{i t}=\left(M_{i t}-M_{i t}^{L}\right) /\left(M_{i t}-X_{i t}\right) \text {. }
$$

\footnotetext{
${ }^{7}$ Bernard, Jensen and Schott [7] note that the list “....represents the world’s most labor-abundant cohort of countries and therefore the set of countries most likely to have an effect on U.S. manufacturing plants”.
} 
Several factors may influence affect unionization rates. These factors include general market conditions affecting unemployment rates, regulations governing labor standards and Social Security, union recruitment strategies, unions' prior success in bargaining, predominant social and political values [33], and employers' opposition to unionization [15]. To control for these factors, we include industry and time fixed effects in our econometric specification. We include industry fixed effects to capture differences in unionization rates across industries that may exist because of industry-specific regulations. We include year (time) fixed effects to account for variation in unionization that can be attributed to a general market condition in a particular year. Because the year fixed effects capture the effect of time trend, we do not include a separate time trend variable.

We also include two additional variables to capture industry protectionism: 1) the foreign direct investments an industry attracts and 2) the average tariff rate for the products associated with an industry. If foreign firms face high entry, then we expect the foreign direct investments to be low in that industry. Similarly, if the average tariff rate for the products of the industry is high, we expect less competition due to foreign companies. Overall, these two factors may influence the level of unionization in an industry if they create protection for domestic firms that would likely affect foreign direct investments, e.g., taxes and transportation costs.

We hand match the OECD's ISIC3-based industry codes to two-digit SIC codes and combine these data with the Harmonized Tariff Schedule (HTS) Code-level tariff data. The tariff data cover the years between 1989 and 2001. Thus, to prevent observations from dropping out of the sample, we assume 1) tariff rates in 2001 prevail in the years between 2001 and 2005 and 2) foreign direct investment is zero if no foreign direct investment is reported in the OECD database. These two assumptions, collectively or separately, do not drive our results. To match the eight-digit harmonized code level tariff data to the two-digit SIC codes, we use the concordance file that links 1989-2006 U.S. HS codes to U.S. SIC codes provided by Pierce and Schott [31]. Of the variables provided in the tariff database, we use the ad valorem portion of the Most Favored Nation (MFN) duty rate as our measure of tariff rate. Because multiple products are associated with two-digit SIC codes, we use the average of these tariff rates as our measure of industry tariff rate. In addition to these factors, we include the level of unionization $(U N I O N)$ as an explanatory variable because a $1 \%$ change in unionization (C3UNION) may have a different economic implication if the level of unionization was, say, $40 \%$ rather than $4 \%$. Excluding the level variable would bias the coefficients if there were a relation between UNION and C3UNION.

In Table 1, we summarize the descriptive statistics of the variables introduced in this section. Of special importance are the variables associated with the incidence of unionization and import penetration. The mean unionization rate $(U N I O N)$ is $17.0 \%$, while the mean three-year change in this rate $(C 3 U N I O N)$ is $-1.23 \%$. The mean of import penetration by low wage countries ( $L W P E N$ ) is $-0.173 \%$, while the same measure for all other countries (OWPEN) is $1.20 \%$. In addition, both of the penetration variable means are associated with relatively very large standard deviations (7.62\% for $L W P E N$ and $31.4 \%$ for OWPEN), a consequence their small denominator (i.e., net imports may be close to zero) creating outliers. This phenomenon is also evinced by the $5^{\text {th }}$ to $95^{\text {th }}$ ranges for the sevariables. Our results, however, are not sensitive to 1) excluding top and bottom outliers, 2) using outlier robust regression methods, and 3) employing other import penetration measures that generate fewer outliers.

Table 1. Summary statistics of variables. This table summarizes the univariate statistics of the primary variables. $U N I O N_{i t}$ is the percentage of employees that were members of a union in industry $i$ and year $t$. C3UNION $N_{i, t} t_{t+3}$ is the change in unionization rate in an industry within three years following the year import penetration is measured. $F D I_{i t}$ is the foreign direct investment; TARIFF $F_{i t}$ is the average of estimated MFN ad valorem rate of products; $L W P E N_{i t}$ is the ratio of low-wage country imports to net imports (x100); and $O W P E N_{i t}$ is the ratio of other than low-wage county imports to net imports (x100). The industry and time subscripts are suppressed in the table headings.

\begin{tabular}{|c|c|c|c|c|c|c|}
\hline & UNION & C3UNION & FDI & TARIFF & LWPEN & OWPEN \\
\hline Mean & 16.980 & -1.231 & 0.049 & 0.051 & -0.173 & 1.203 \\
\hline Median & 14.395 & -1.099 & 0.000 & 0.028 & 0.122 & 1.204 \\
\hline Std. Dev & 11.738 & 4.166 & 0.149 & 0.094 & 7.620 & 31.400 \\
\hline P5 & 1.895 & -7.276 & -0.001 & 0.001 & -0.802 & -8.441 \\
\hline P25 & 7.680 & -2.778 & 0.000 & 0.011 & 0.000 & -0.405 \\
\hline P75 & 24.299 & 0.264 & 0.025 & 0.058 & 0.504 & 2.710 \\
\hline P95 & 39.488 & 4.422 & 0.312 & 0.112 & 1.750 & 11.501 \\
\hline$N$ & 531 & 469 & 531 & 531 & 531 & 531 \\
\hline
\end{tabular}




\section{Empirical Design and Results}

If competition originates from low-wage countries, employers' opposition to unionization and/or unions' inadequate bargaining power to negotiate (negotiation power hypothesis), then we predict a negative relation between import penetration originating from low-wage countries and unionization rates. We use the following specification to test this hypothesis:

$$
\begin{aligned}
\text { C3UNION }_{i, t \text { to } t+3}= & \beta_{0}+\beta_{1} \text { LWPEN }_{i t}+\beta_{2} \text { UNION }_{i, t}+\beta_{3} \text { FDI }_{t}+\beta_{4} \text { TARIFF }_{t} \\
& +\beta_{5} \text { Industry Fixed Effects }+\beta_{6} \text { Year Fixed Effects. }
\end{aligned}
$$

To obtain exogenous variation in unionization, we instrument the current level of unionization by its lagged values. For ease of reading, where appropriate we sometimes denote a variable lagged one year as $\operatorname{Lag}_{1}($.) and if lagged two years is $\operatorname{Lag}_{2}($.) instead of using subscripts such as $t-1$ and $t-2$, respectively.

We report the results of the estimation and the specification tests for the instrument in Table 2. The $R^{2}$ of first-stage regression is 0.40 , and the coefficient of the instrument is statistically significant. The under- identification test also shows that the excluded instrument, $\operatorname{Lag}_{1}(U N I O N)$, is relevant, i.e., correlated with the endogenous regressor, UNION. The weak identification tests show that our instrument is not a weak instrument, suggesting that $\operatorname{Lag}_{1}(U N I O N)$ is not a poor predictor of UNION. Overall, the two statistical tests indicate that $\operatorname{Lag}_{1}(U N I O N)$ carries desirable properties as an instrument.

Because our model is exactly identified (number of instruments is equal to number of instrumented variables), we cannot test the assumption that the instruments are not correlated with the error term in the equation of interest. If the adjustment costs are high, it is plausible to expect lagged unionization to predict current unionization; however, it is less clear whether lagged unionization would predict change in unionization in the coming three years (the error term contains unaccounted variation in unionization changes with the future three years). The time gap between the instrument $(t-1)$ and the error terms $(t+1$ to $t+3)$ provide some assurance that the dis-

Table 2. We use the instrumental variables method to estimate the parameters of Equation (5). All variables are defined in Table 1. In the first four (last two) columns, we calculate import penetration using imports and exports of all low wage countries (China and India only). UWETS (under identification) refers to the Kleibergen-Paaprk LM F-statistic and WWETS (weak identification) refers to the Cragg-Donaldwald $F$-statistic. $P$-values are reported in brackets. In under the identification

\begin{tabular}{|c|c|c|c|c|c|c|}
\hline & First Stage & Second Stage & First Stage & Second Stage & First Stage & Second Stage \\
\hline & UNION & C3UNION & UNION & C3UNION & UNION & C3UNION \\
\hline \multirow{2}{*}{ LWPEN } & -0.08 & -1.88 & & & -0.37 & -3.71 \\
\hline & {$[0.890]$} & {$[0.002]$} & & & {$[0.794]$} & {$[0.001]$} \\
\hline \multirow{2}{*}{ OWPEN } & & & -0.14 & -.61 & & \\
\hline & & & {$[0.518]$} & {$[0.001]$} & & \\
\hline \multirow{2}{*}{ FDI } & -1.47 & 0.52 & -1.48 & 0.51 & -1.70 & 0.44 \\
\hline & [0.109] & {$[0.470]$} & {$[0.106]$} & {$[0.480]$} & {$[0.058]$} & {$[0.557]$} \\
\hline \multirow{2}{*}{ TARIFF } & -1.24 & 6.45 & -1.25 & 6.45 & -1.58 & 6.51 \\
\hline & {$[0.865]$} & {$[0.527]$} & {$[0.863]$} & {$[0.526]$} & {$[0.822]$} & {$[0.519]$} \\
\hline \multirow{2}{*}{ UNION } & & -0.22 & & -0.22 & & -0.22 \\
\hline & & {$[0.013]$} & & {$[0.013]$} & & {$[0.024]$} \\
\hline \multirow{2}{*}{ Instrument: $\operatorname{Lag}_{1}(U N I O N)$} & 0.64 & & 0.63 & & 0.62 & \\
\hline & {$[0.000]$} & & {$[0.000]$} & & {$[0.000]$} & \\
\hline Industry Fixed Effects & Included & Included & Included & Included & Included & Included \\
\hline Year Fixed Effects & Included & Included & Included & Included & Included & Included \\
\hline Constant & Included & Included & Included & Included & Included & Included \\
\hline$N$ & 438 & 438 & 438 & 438 & 438 & 438 \\
\hline$R^{2}$ & 0.40 & 0.15 & 0.40 & 0.15 & 0.38 & 0.16 \\
\hline UWETS & & $10.52^{\mathrm{a}}$ & & $10.53^{\mathrm{a}}$ & & $10.41^{\mathrm{a}}$ \\
\hline WWETS & & $248.44^{\mathrm{a}}$ & & $248.46^{\mathrm{a}}$ & & $233.14^{\mathrm{a}}$ \\
\hline
\end{tabular}
and weak identification tests, (a) and (b) refer to statistical significance at the 0.01 and 0.05 levels, respectively. 
tant historical levels of unionization may not necessarily cause future unionization level changes. When we apply lagged values of unionization as an instrument to the current unionization level to obtain exogenous variation in unionization, we find that the economic impact of import penetration on the future unionization rate is -1.88 and statistically significant. ${ }^{8}$

In the third and fourth column of Table 2, we find that the impact of import penetration originating from other-wage countries $(O W P E N)$ on unionization rate change is one-third that of low-wage countries, suggesting that imports from low-wage countries have distinct effects. In the last two columns of Table 2, we replicate the main specification using penetrations measures based on imports originating from India and China only. The coefficients of $L W P E N$ are noticeably more negative than those reported in the first two columns, confirming the observation that these two countries are dominant importers in most of the industries.

In Table 3, we extend our analysis by using lagged values of unionization, FDI, and TARIFF as instruments for their current value. As suggested before, these variables may be correlated with the error term in the presence of omitted variables. For example, if industries with higher tariffs enjoy protection from politicians who

Table 3. Change in unionization and import penetration from low-wage countries. The first three columns of this table report the estimates of instrumental variables estimation in which $\operatorname{Lag}_{1}(U N I O N), \operatorname{Lag}_{1}(F D I)$, and $\operatorname{Lag}_{1}(T A R I F F)$ are used as instruments for UNION, FDI, and TARIFF. The last column reports the estimates of second stage of instrumental variables regression in which unionization (UNIONCOV) and change in unionization (C3UNIONCOV) are defined by the ratio of number of covered employees (rather than union members) to total number of employees. All other variables are defined in Table 1. UWETS (under identification) refers to the Kleibergen-Paaprk LM F-statistic and WWETS (weak identification) refers to the Cragg-Donald Wald $F$-statistic. $P$-values are reported in brackets. In under the identification and weak identification tests, $\left({ }^{a}\right)$ and $\left({ }^{b}\right)$ refer to statistical significance at the 0.01 and 0.05 levels, respectively.

\begin{tabular}{|c|c|c|c|c|c|}
\hline & First Stage & First Stage & First Stage & Second Stage & Second Stage \\
\hline & UNION & FDI & TARIFF & C3UNION & C3UNIONCOV \\
\hline \multirow{2}{*}{ LWPEN } & -0.024 & -0.008 & -0.004 & -1.99 & -2.01 \\
\hline & [0.967] & {$[0.741]$} & {$[0.163]$} & {$[0.001]$} & {$[0.001]$} \\
\hline \multirow{2}{*}{ FDI } & & & & 2.77 & 2.75 \\
\hline & & & & [0.195] & {$[0.186]$} \\
\hline \multirow{2}{*}{ TARIFF } & & & & 0.904 & -0.756 \\
\hline & & & & {$[0.936]$} & {$[0.947]$} \\
\hline \multirow{2}{*}{ UNION } & & & & -0.24 & \\
\hline & & & & [0.017] & \\
\hline \multirow{2}{*}{ UNIONCOV } & & & & & -0.21 \\
\hline & & & & & {$[0.039]$} \\
\hline \multirow{2}{*}{ Instrument: $\operatorname{Lag}_{1}(U N I O N)$} & 0.645 & -0.002 & -0.001 & & \\
\hline & {$[0.000]$} & [0.135] & [0.227] & & \\
\hline \multirow{2}{*}{ Instrument: $\operatorname{Lag}_{1}(F D I)$} & -0.946 & 0.411 & -0.009 & & \\
\hline & {$[0.230]$} & [0.009] & {$[0.170]$} & & \\
\hline \multirow{2}{*}{ Instrument: $\operatorname{Lag}_{1}($ TARIFF) } & 2.145 & -0.048 & 0.810 & & \\
\hline & {$[0.751]$} & [0.184] & {$[0.000]$} & & \\
\hline Industry Fixed Effects & Included & Included & Included & Included & Included \\
\hline Year Fixed Effects and Constant & Included & Included & Included & Included & Included \\
\hline$N$ & 438 & 438 & 438 & 438 & \\
\hline$R^{2}$ & 0.40 & 0.18 & 0.70 & 0.19 & \\
\hline UWETS & & & & $5.17^{\mathrm{b}}$ & $9.83^{\mathrm{a}}$ \\
\hline WWETS & & & & 25.21 & 5.86 \\
\hline
\end{tabular}

\footnotetext{
${ }^{8}$ In unreported results, we estimate specification (1) using unionization rate changes for the one and two years instead of three years. We find that the magnitude of the import penetration coefficient is insignificant for the first year. For the second year, however, the effect is statistically significant, and its magnitude is $37 \%$ of the magnitude reported in Table 2 . This suggests that it takes more than two years for employees, firms, and unions to adjust to a new environment that includes cheaper foreign imports.
} 
create barriers to foreign competitors, then the error term is likely to be correlated with the tariff rate if we cannot measure political protection. The statistical properties of both $\operatorname{Lag}_{1}(F D I)$ and $\operatorname{Lag}_{1}($ TARIFF) as instruments are similar to that of $\operatorname{Lag}_{1}(U N I O N)$. The results in Table 3 indicate that the coefficient of the low-wage penetration $(-1.99)$ is very close to what we report in Table $2(-1.88)$.

In a right-to-work state, the law gives employees the right to decide whether to become labor union members. According to U.S. federal labor laws, unions are required to negotiate the same wage settlement for all employees in the bargaining unit regardless of their membership status. Eren [34] finds that members enjoyed, on average, a wage premium of $9 \%$ over comparable covered nonmembers. Using number of members, rather than number of covered employees, to calculate unionization rate in right-to-work states would underestimate the total amount of covered members in collective bargaining. This suggests that if industries in the right-to-work states were attracting more import penetration from low-wage countries, then reduction in a unionization measure that ignores "covered but not-member" labor would be incorrectly attributed to switches from being "member" to "covered but not-member" as the loss of labor unions' negotiation power.

We replicate our main results with a unionization measure that also incorporates covered nonmembers and obtain similar results. In other words, we define unionization as follows:

$$
\text { UNIONCOV }_{i, t}=100\left(\text { Covered Members }_{i, t} / \text { Total Employees }_{i, t}\right) \text {. }
$$

In the last column of Table 3, we report the results of instrumental variables regression's second stage, which uses lagged values of UNIONCOV, FDI, and TARIFF as instruments for these variables. Our results indicate that this alternate definition of unionization is also negatively related to import penetration.

In the analysis presented thus far, we assumed import penetration is exogenous. In Table 4 we study the implications of modeling import penetration as an endogenous variable. We use tariff and lagged import penetration as instruments of import penetration. Lagged import penetration is likely to be related to the current year's penetration because importing countries may find it costly to change their production mix and strategies in the short run. Similarly, tariff rates of the previous year are likely to be related to import penetration because countries are not likely to respond to tariff changes quickly.

We use the Arellano and Bond [35] approach to measure the relationships. Specifically, we take the first difference in both dependent and independent variables to eliminate the fixed effects across panels. Next, we use lagged levels of the variables as instruments for the first differenced variables. In our case, because UNION and $F D I$ are considered endogenous, lags of the second order are potentially valid instruments. In other words, we use $L W P E N_{i t-2}, U N I O N_{i t-2}$ and $F D I_{i t-2}$ as instruments for $\triangle L W P E N_{i t}, \Delta U N I O N_{i t}$, and $\triangle F D I_{i t}$, where $\Delta$ is the difference operator. ${ }^{9}$ The results in Table 4 indicate that the sign of change in import penetration is negative but statistically insignificant $(p=0.16)$. This result could simply be due to imperfect instruments, because the null hypothesis that the instruments are weak cannot be rejected by the Cragg-Donald Wald F-statistic (0.12).

\section{Conclusions}

Competition created by international trade forces firms and labor unions to adjust to new environments. Bernard, Jensen and Schott [7] provide compelling evidence that firms exposed to imports from low-wage countries have lower growth rates and lower survival probabilities. These firms change their business focus to include more capital- and skill-intensive processes. In this paper, we present evidence that complements their findings by analyzing the effects of low-wage country imports on unionization rates.

We find that import penetration originating from low-wage countries is negatively related to unionization rates. This finding suggests that firms become reluctant to agree with unions that ask for sticky labor costs and multi-year contracts as a result of declining company profit margins. It also suggests that employees may find it less beneficial to join a union by predicting unions' loss of negotiation power in the new era. Our findings indicate that increasing the low-wage country import penetration by $1 \%$ reduces unionization rates by $1.88 \%$ within three years following import penetration after controlling for several factors that have been argued in the literature to affect unionization rates. Using the last year of our sample (2008), as a reference point this percentage translates into a loss of roughly 640,000 union members at the end of the 3-year period. If we consider China and India as the only low-wages countries the $1 \%$ increase in imports increases the reduction to $-3.71 \%$.

More broadly, our analysis raises the question about the net effect of import penetration coming from low-

${ }^{9}$ Recall that we also denote lagged variables using the $L a g$ operator so that, e.g., $\operatorname{Lag}_{2}(L W P E N)$ is equivalent to $L W P E N_{i t-2}$. 
Table 4. Changes in unionization and endogenous import penetration. This table reports the first and second stage values of instrumental variables estimation in which lag unionization is used as an instrument for current unionization. All variables are defined in Table 1. UWETS (under identification) refers to the Kleibergen-PaaprkLM F-statistic and WWETS (weak identification) refers to the Cragg-Donald Wald $F$-statistic. $P$-values are reported in brackets. In under the identification and weak identification tests, $\left({ }^{\mathrm{a}}\right)$ and $\left({ }^{\mathrm{b}}\right)$ refer to statistical significance at the 0.01 and 0.05 levels, respectively.

\begin{tabular}{|c|c|c|c|c|}
\hline & First Stage & First Stage & First Stage & Second Stage \\
\hline & $\triangle L W P E N$ & $\triangle U N I O N$ & $\Delta F D I$ & $\triangle C 3 U N I O N$ \\
\hline \multirow{2}{*}{$\triangle L W P E N$} & & & & -99.79 \\
\hline & & & & {$[0.165]$} \\
\hline \multirow{2}{*}{$\triangle U N I O N$} & & & & -0.54 \\
\hline & & & & {$[0.672]$} \\
\hline \multirow{2}{*}{$\triangle F D I$} & & & & -11.80 \\
\hline & & & & {$[0.451]$} \\
\hline \multirow{2}{*}{ Instrument: $\triangle T A R I F F$} & 0.01 & 1.98 & 0.00 & \\
\hline & {$[0.768]$} & {$[0.610]$} & {$[0.946]$} & \\
\hline \multirow{2}{*}{ Instrument: $\operatorname{Lag}_{2}(L W P E N)$} & -0.02 & -1.12 & 0.01 & \\
\hline & [0.591] & {$[0.136]$} & {$[0.697]$} & \\
\hline \multirow{2}{*}{ Instrument: $\mathrm{Lag}_{2}(\mathrm{UNION})$} & 0.00 & -0.13 & 0.00 & \\
\hline & {$[0.782]$} & {$[0.034]$} & {$[0.650]$} & \\
\hline \multirow{2}{*}{ Instrument: $\operatorname{Lag}_{2}(F D I)$} & 0.00 & -1.09 & -0.24 & \\
\hline & {$[0.855]$} & {$[0.231]$} & {$[0.224]$} & \\
\hline Year Fixed Effects & Included & Included & Included & Included \\
\hline Constant & Included & Included & Included & Included \\
\hline$N$ & 407 & 407 & 407 & 407 \\
\hline$R^{2}$ & 0.006 & 0.019 & 0.045 & \\
\hline UWETS & & & & 1.08 \\
\hline WWETS & & & & 0.13 \\
\hline
\end{tabular}

wage countries. Many heterogeneous firm models of international trade that predict output and employment are directed toward higher-productivity firms, leading to an increase in average industry productivity. Our evidence shows that at least part of this increase in productivity is associated with a reduction in the union participation rate. Whether this trade-off is advantageous to society has yet to be decided. Some arguments have been made to support the assertion that union membership has benefits for its members, including better health care, sounder pensions, and safer work environment. One of the goals of government is to find an appropriate socially acceptable balance between various trade restrictions promulgated by international trade agreements and the organizational structure of the domestic labor force. To perform this task fairly and successfully, the government must understand not only the economic but also the social trade-offs involved.

\section{References}

[1] Smith, A. (1776) An Inquiry into the Nature and Cause of the Wealth of Nations. Cannan, E., Ed., 1904, Methuen \& Co., Ltd., London. http://www.econlib.org/library/Smith/smWN.html.

[2] Ricardo, D. (1817) On the Principles of Political Economy and Taxation. In: Sraffa, P., Ed., with the Collaboration of Dobb, M.H., The Works and Correspondence of David Ricardo, 11 Vols, 1951-1973, Cambridge University Press, Cambridge. http://www.econlib.org/library/Ricardo/ricP.html.

[3] Griswold, D. (2010) Unions, Protectionism, and U.S. Competitiveness. Cato Journal, 30, 181-196.

[4] Schneider, H. (2010) Obama, Lee Outlined U.S.-Korea Trade Deal in Seoul, Official Says. Washington Post, December 6. http://voices.washingtonpost.com/political-economy/2010/12/post_1.html

[5] Simmons, B.A. (1994) Who Adjusts? Domestic Sources of Economic Policy during the Interwar Years. Princeton University Press, Princeton, NJ. 
[6] Bailey, M. and Bosworth, B. (2014) U.S. Manufacturing: Understanding Its Past and Its Future Potential. Journal of Economic Perspectives, 28, 3-26.

[7] Bernard, A.B., Jensen, J.B. and Schott, P.K. (2006) Survival of the Best Fit: Exposure to Low-Wage Countries and the (Uneven) Growth of U.S. Manufacturing Plants. Journal of International Economics, 68, 219-237. http://dx.doi.org/10.1016/j.jinteco.2005.06.002

[8] Chen, H., Kacperczyk, M. and Ortiz-Molina, H. (2009) Labor Unions, Operating Flexibility, and the Cost of Equity. AFA 2008 New Orleans Meetings Paper.

[9] Robinson, L. (2008) Why Detroit Has an Especially Bad Union Problem. The Wall Street Journal, December 30. http://www.wsj.com/articles/SB123060246925441479

[10] Mishel, L. (1986) The Structural Determinants of Union Bargaining Power. Industrial and Labor Relations Review, 40, 90-104. http://dx.doi.org/10.1177/001979398604000107

[11] Abraham, K.G. and Medoff, J. (1984) Length of Service and Layoffs in Union and Nonunion Work Groups. Industrial and Labor Relations Review, 38, 87-97. http://dx.doi.org/10.1177/001979398403800109

[12] Mitchell, D.J.B. (1985) Wage Flexibility: Then and Now. Industrial Relations, 24, 266-279. http://dx.doi.org/10.1111/j.1468-232x.1985.tb00995.x

[13] Wunnava, P. and Okunade, A.A. (1996) Countercyclical Union Wage Premium? Evidence for the 1980s. Journal of Labor Research, 17, 289-296. http://dx.doi.org/10.1007/BF02685846

[14] McLaughlin, D.B. and Fraser, D.A. (1984) Collective Bargaining: The Next Twenty Years. Annals of the American Academy of Political and Social Science, 473, 33-39. http://dx.doi.org/10.1177/0002716284473001004

[15] Waddington, J. and Kerr, A. (2002) Unions Fit for Young Workers? Industrial Relations Journal, 33, $298-315$. http://dx.doi.org/10.1111/1468-2338.00237

[16] Bernard, A.B., Jensen, J.B., Redding, S. and Schott, P.K. (2007) Firms in International Trade. Journal of Economic Perspectives, 21, 105-130. http://dx.doi.org/10.1257/jep.21.3.105

[17] Bernard, A.B., Eaton, J., Jensen, J.B. and Kortum, S.S. (2003) Plants and Productivity in International Trade. American Economic Review, 93, 1268-1290. http://dx.doi.org/10.1257/000282803769206296

[18] Melitz, M.J. and Ottaviano, G.I.P. (2008) Market Size, Trade, and Productivity. Review of Economic Studies, 75, 295-316. http://dx.doi.org/10.1111/j.1467-937X.2007.00463.x

[19] Melitz, M.J. (2003) The Impact of Trade on Intra-Industry Reallocations and Aggregate Industry Productivity. Econometrica, 71, 1695-1725. http://dx.doi.org/10.1111/1468-0262.00467

[20] Krugman, P.R. (1981) Intraindustry Specialization and Gains for Trade. Journal of Political Economy, 89, 959-973. http://dx.doi.org/10.1086/261015

[21] Davis, D.R. and Harrigan, J. (2011) Good Jobs, Bad Jobs, and Trade Liberalization. Journal of International Economics, 84, 26-36. http://dx.doi.org/10.1016/j.jinteco.2011.03.005

[22] Felbermayr, G., Prat, J. and Schmerer, H.-J. (2011) Globalization and Labor Market Outcomes: Wage Bargaining, Search Frictions, and Firm Heterogeneity. Journal of Economic Theory, 161, 39-73. http://dx.doi.org/10.1016/j.jet.2010.07.004

[23] Uysal, P., Yotov, Y.V. and Zylkin, T. (2015) Firm Heterogeneity and Trade-Induced Layoffs: An Empirical Investigation. European Economic Review, 75, 80-97. http://dx.doi.org/10.1016/j.euroecorev.2015.01.006

[24] Egger, H. and Kreickemeier, U. (2009) Firm Heterogeneity and the Labor Market Effects of Trade Liberalization. International Economic Review, 50, 187-216.

[25] Helpman, E., Itskhoki, O., Muendler, M.-A. and Redding, S. (2012) Trade and Inequality: From Theory to Estimation. NBER Working Paper No. 17991. http://dx.doi.org/10.3386/w17991

[26] Cosar, K., Guner, N. and Tybout, J. (2013) Firm Dynamics, Job Turnover, and Wage Distributions in an Open Economy. IZA Discussion Paper No. 7718.

[27] Kondo, I. (2013) Trade Reforms, Foreign Competition, and Labor Market Adjustments in the US. FRB International Finance Discussion Paper No. 1095. http://dx.doi.org/10.2139/ssrn.2419956

[28] Yotov, Y.V. (2013) Trade Adjustment, Political Pressure, and Trade Protection Patterns. Economic Inquiry, 51, 18671885. http://dx.doi.org/10.1111/j.1465-7295.2012.00504.X

[29] Grossman, G.M. and Helpman, E. (1994) Protection for Sale. American Economic Review, 84, 833-850.

[30] Hirsch, B.T. and Macpherson, D.A. (2003) Union Membership and Coverage Database from the Current Population Survey: Note. Industrial and Labor Relations Review, 56, 349-354. http://dx.doi.org/10.1177/001979390305600208

[31] Pierce, J. and Schott, P. (2011) A Concordance between Ten-Digit US Harmonized System Codes and SIC/NAICS Product Classes and Industries. FEDS Working Paper No. 2012-15. http://dx.doi.org/10.2139/ssrn.2051021 
[32] Connolly, R.A., Hirsch, B.T. and Hirschey, M. (1986) Union Rent Seeking, Intangible Capital, and Market Value of the Firm. Review of Economics and Statistics, 68, 567-577. http://dx.doi.org/10.2307/1924515

[33] Haynes, P., Vowles, J. and Boxall, P. (2005) Explaining the Younger-Older Worker Union Density Gap: Evidence from New Zealand. British Journal of Industrial Relations, 43, 93-116. http://dx.doi.org/10.1111/j.1467-8543.2005.00346.x

[34] Eren, O. (2009) Does Membership Pay Off for Covered Workers? A Distributional Analysis of the Free Rider Problem. Industrial and Labor Relations Review, 62, 367-380. http://dx.doi.org/10.1177/001979390906200306

[35] Arellano, M. and Bond, S. (1991) Some Tests of Specification for Panel Data: Monte Carlo Evidence and an Application to Employment Equations. Review of Economic Studies, 58, 277-297. http://dx.doi.org/10.2307/2297968

Appendix. Low-Wage Countries

\begin{tabular}{cccc}
\hline Afghanistan & China & India & Pakistan \\
Albania & Comoros & Kenya & Rwanda \\
Angola & Congo & Laos & Samoa \\
Armenia & Equatorial Guinea & Lesotho & Sao Tome \\
Azerbaijan & Eritrea & Madagascar & Sierra Leone \\
Bangladesh & Ethiopia & Malawi & Somalia \\
Benin & Gambia & Maldives & Sri Lanka \\
Bhutan & Georgia & Mali & St. Vincent \\
Burkina Faso & Ghana & Sudan \\
Burundi & Guinea & Moldova & Togo \\
Cambodia & Guinea-Bissau & Mozambique & Uganda \\
Central African Rep. & Guyana & Nepal & Vietnam \\
Chad & Haiti & Niger & Yemen \\
\hline
\end{tabular}

Source: [7]. 